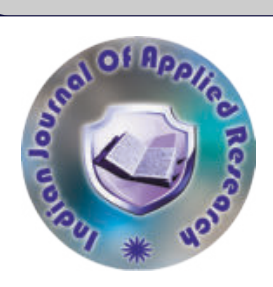

Monika Massey*

\section{Dr Chintamani} Chauhan

\section{Nursing}

\title{
IMPACT OF STRUCTURED INFORMATION MODULE ON KNOWLEDGE REGARDING OVER USAGE OF MOBILE IN PREGNANCY
}

\section{ABSTRACT} Cell phone radiation causes many ill affect pregnant women's physical, mental, and emotional state. This paper aims to evaluate a structured informational module on facts about the impact of overuse of mobile phones during pregnancy this study was conducted in the SAIMS college of nursing, in this study 80 baccalaureate 3rd and 4 th year student was selected by Non probability sampling technique Data was collected through a structured questionnaire. it was found the mean value of $11.88 \pm 4.00$ in pre test and $23.71 \pm 2.70$ was found in post test the mean difference of knowledge of impact of over usage of mobile phone in pregnancy 11.83 point the $\mathrm{z}$ statistic value is 35.80 was strongly significant and $p$ value is $p<0.001$ The present study attempted to find out the effectiveness of structured informational module regarding over usage mobile during pregnancy among baccalaureate nursing student was strongly effective

KEYWORDS : Baccalaureate nursing students, structured informational module, Mobile phone, Electromagnetic radiation, Miscarriage, Birth defect.

\section{INTRODUCTION: -}

Cell phone is wireless a long reach and compact electronic gadget which is utilized for correspondence, notwithstanding the standard voice capacity of a phone. The advancements of versatile correspondence have moved quickly. During this energizing excursion the wireless radiations causes numerous evil impacts influencing the physical mental and the enthusiastic conditions of pregnant women. Radiations effectively flip certain qualities in the mitochondria results in gene toxic impacts. The harmed mitochondria make cells no longer to play out the errand and spillage Happen. In the event that this quality grouping is adjusted in pregnant ladies. It causes solid formative issue in later existence of kids and during pregnancy

A study was conducted by Suman gala 2012. 50 antenatal mothers in udipi area emergency clinic Karnataka non-like hood advantageous testing technique. In the current examination. It was discovered that dominant part $20(40 \%)$ of the antenatal ladies were in the age gathering of 21-25 years, lion's share $36(72 \%)$ of the antenatal ladies were having a place with Hindu religion, larger part $28(56 \%)$ of the antenatal ladies had a place with joint family, greater part $21(42 \%)$ of the antenatal ladies had instruction up to auxiliary, dominant part $28(56 \%)$ of the antenatal ladies were house spouses, lion's share $18(36 \%)$ of the antenatal ladies family pay went between Rs 3001- $5000 /$ - , larger part $18(36 \%)$ of the antenatal ladies gestational period went from 13-28 weeks. the mean posttest information score (18.88 \pm 3.12) was higher than the mean pre-test information score (10.96 \pm 3.36) which indicated that there is exceptionally huge distinction between the mean pre-test and post-test information scores The determined esteem $(\mathrm{t} 49=11.09, \mathrm{p}<0.05)$ was more prominent than the table worth $(\mathrm{t} 49=1.67 \mathrm{p}<0.05)$

\section{OBJECTIVES}

1) To assess the pre-test knowledge score regarding impact of over usage of mobile in pregnancy among baccalaureate nursing student

2) To assess the knowledge regarding impact of over usage of mobile in pregnancy among baccalaureate nursing students after post test

3) To assess the effectiveness of structured information module on knowledge regarding impact of over usage of mobile in pregnancy among baccalaureate nursing students

4) To find out the association between pre-test and post test score with their selected demographic variables.

\section{HYPOTHESIS:-}

$\mathbf{R H}_{01-}$ There will be no significant difference between pre-test and posttest knowledge scores regarding impact of over usage of mobile in pregnancy.

$\mathbf{R H}_{1-}$ There will be significant difference between pre-test and post -test knowledge scores regarding impact of over usage of mobile in pregnancy

$\mathbf{R H}_{02}$ There will be no significant association between pretest and posttest knowledge scores with selected socio demographics variables

$\mathbf{R H}_{2 .}$ There will be significant association between the pretest and posttest knowledge scores with selected socio demographic variables.

\section{METHODOLOGY:-}

A pre-experimental research approach was one group pretest posttest design. The samples were recruited by non-probability convenient sampling technique. The size of population included this study was 80 B.sc Nursing $3^{\mathrm{RD}}$ and $4^{\text {th }}$ year students which were selected according to inclusive and exclusive criteria. They were a structured informational module to give their response to assess the knowledge regarding over usage of mobile during pregnancy

\section{RESULT:}

- According to age major part $(28,35 . \%)$ of population of baccalaureate nursing students was more frequently belonged to the lower age group of 22-23 years

- Genders of baccalaureate nursing students revealed that most of the studied $(69,86.3 \%)$ of population to be female

- Major part (46,57.5\%) of population of baccalaureate nursing students were more frequently pursuing b.sc nursing IV year

- Analysis of previous knowledge of baccalaureate nursing students indicated that more than half $(57.5 \%)$ of the baccalaureate nursing students had previous knowledge about of over usage of mobile phone in pregnancy

- Analysis about sources of previous knowledge about impact of over usage of mobile phone in pregnancy indicated that most (24, $30.0 \%$ ) of the baccalaureate nursing students

Table No-1 Frequency and distribution according to demographic variables

\begin{tabular}{|l|l|l|}
\hline Characteristic of sample & frequency & percent \\
\hline Age of baccalaureate nursing students & 24 & 30.0 \\
\hline $21 \mathrm{yr}$ & 28 & 35.0 \\
$22 \mathrm{yr}$ & 28 & 35.0 \\
$23 \mathrm{yr}$ & 69 & 86.3 \\
\hline Gender of baccalaureate nursing students & 11 & 13.8 \\
\hline Female & \multicolumn{2}{|l|}{} \\
Male & 34 & 42.5 \\
\hline Educational status of baccalaureate nursing students & 57.5 \\
\hline b.sc(n) 3 $3^{\text {rd }}$ yr & 46 & \\
b.sc(n)4 $4^{\text {th }}$ yr & \\
\hline Previous knowledge of baccalaureate nursing & \\
students & 34 \\
\hline No & 46 & 42.5 \\
Yes & 57.5 \\
\hline Source of Previous knowledge of baccalaureate nursing students \\
\hline None & 36 \\
Mass Media & 24 & 45.0 \\
Health team worker & 2 \\
Educational Institute & 18 & 2.5 \\
\hline
\end{tabular}


Comparison of pretest and posttest knowledge score regarding over usage of mobile during pregnancy among baccalaureate nursing students

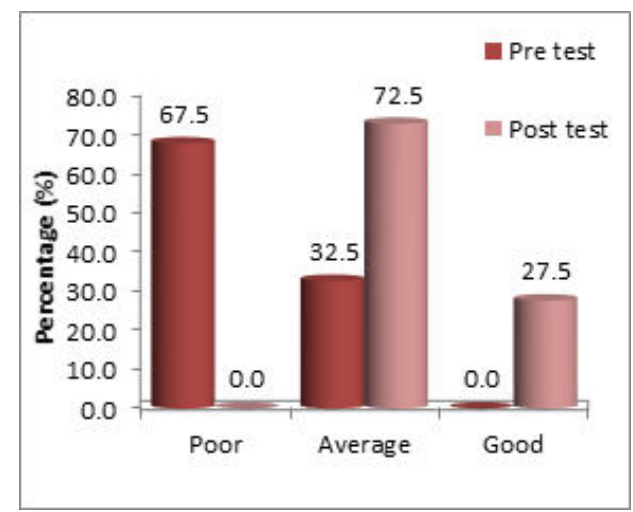

Figure no 1 bar diagram showing the comparison in knowledge levels among baccalaureate nursing students

\section{LIMITATION}

- The study was conducted in a limited time period.

- Sample drawn for the study was only from SAIMS nursing college

- The study was limited to a small population

\section{CONCLUSION:-}

The present study attempted to find out the effectiveness structured informational module regarding impact over usage of mobile during pregnancy among baccalaureate nursing students may consider as an effective tools when there is a need in lacking bridging and modifying the knowledge regarding impact of over usage of mobile in pregnancy.

\section{REFERENCES:-}

Bennet, V.Ruth., Brown, Linda K., "Myles Text Book For Mid wives"., Philadelphia: Churchill Living stone., 2001, page no 50-59

2. Dutta, D.C., "Text book of obstetrics"., Calcutta: New central book agency., 2000.,Page no 89-99

3. Effect of cell phone radiation during pregnancy:URL:http://ezinearticles.com/?Effectsof-cell-phone-radiation-pregnancy\&i $=4377214$

4. Exposure to magnetic field non-ionizing radiation and the risk of miscarriage, DE Kun, HongChenhttps://www.nature.com/articles/s41598-017-16623-8

5. Malignant brain tumors diagnosed L Hardell www. ncbi. nlm. nih. gov/ pmc/ articles/ PMC3834325 